\title{
Temporal and spatial immunolocalization of osteopontin in the repair of orthopaedic bone defects treated with demineralized bone matrix
}

\author{
Audisio, S.A. ${ }^{l}$; Vaquero, P.G. ${ }^{l}$; Verna E.C. ${ }^{1}$; Cristofolini, A.L. ${ }^{2}$; Merkis, C.I. ${ }^{2}$ \\ ${ }^{I}$ Faculty of Veterinary Science, National University of La Pampa, La Pampa, Argentina \\ ${ }^{2}$ Electronic Microscopic Area, Agronomy and Veterinary Faculty, National University of Río \\ Cuarto, Córdoba, Argentina
}

E-mail:saudisio@vet.unlpam.edu.ar

\section{SUMMARY}

Osteopontin (OPN) is the most abundant non-collagen protein in the bone matrix, where it fulfils the function of cellular adhesion and biomineralization. In the present work, the authors report the temporal and spatial localization of OPN during the repair of experimental orthopaedic bone defects treated with demineralized bone matrix (DBM) processed by the authors. 30 rabbits were used, which were given an orthopaedic bone defect of critical size in one of the radiuses, which was filled with DBM. The rabbits were euthanized in groups of 5 individuals at days 7, 15, 21, 30, 60 and 150. Histological cuts were immunomarked to establish the spatial and temporal immunomarcation of OPN. The histological cuts were observed with an optic microscope with which histological images were captured and analysed with the ImageJ software. The image analysis allowed the authors to establish the optic density (OD) and the integrated optic density (IOD). The data was analysed with the ANOVA and Fischer LSD tests. At day 7, the presence of OPN was observed only in the DBM particles, where the OD was 0.08 and the IOD was 1.64; at day 15, OPN marked different sites of collagen condensations and cells contained in the interior of the matrix. In this period the OD was 0.096 and the IOD, 9.26. At days 21 and 30, the OPN immunosignalled osteocytes, osteoblasts, osteoclasts and hypertrophic chondrocytes in the bone trabeculae adjacent 
to the ossification zones. At day 21 the OD was 0.17 and IOD 6.22. At day 30 , the OD was 0.14 and the IOD 2.52. At days 60 and 150, OPN was evenly distributed in the new bone matrix with an OD: 0.10 and IOD: 0.48 , and OD: 0.35 and IOD: 3.80 , respectively. The OD and IOD showed significant differences ( $p<=0.05$ ) between days $7,15,21$ and 30 ; and there was no difference at days 60 and $150(p=0.05)$. OPN was found in the DBM particles: it increased the optic densities at day 15 and it diminished at day 60, after which it increased the OD and IOD again until day 150. It was established that the OPN immunoexpressed during the repair process in indifferentiated cells, osteoprogenitor chondrocytes and osteoblasts. The variation of OD and IOD allowed the authors to establish that the greatest degree of immunoexpression of OPN was at day 15 after repair initiated. On the other hand, the increase registered between days 60 and 150 post treatment was due to the biomineralization of the bone matrix.

Key words: Rabbit, bone, osteopontin, inmunomarcation, demineralized bone matrix

\section{Inmunolocalización temporal y espacial de osteopontina en la reparación de defectos óseos ortopédicos tratados con matriz ósea desmineralizada}

\section{RESUMEN}

La osteopontina (OPN) es la proteína no colágena que más abunda en la matriz ósea, donde cumple funciones de adhesión celular y biomineralización. En el presente trabajo se informa la localización temporal y espacial de la OPN durante la reparación de defectos óseos ortopédicos tratados con matriz ósea desmineralizada (MOD). Se emplearon 30 conejos a los que se les practicó un defecto óseo ortopédico de tamaño crítico en uno de sus radios. Los defectos se rellenaron con MOD obtenida según protocolo previamente informado. Los conejos fueron sacrificados en grupos de 5 a los 7, 15, 21, 30, 120 y 150 días de los cuales se recuperaron los defectos para identificar las estructuras histológicas y establecer la inmunomarcación espacial y temporal de OPN. Se realizaron cortes histológicos de los defectos que se tiñeron con hematoxilina y eosina (HE) e inmunomarcaron según técnica inmunohistológica. Los cortes inmunomarcados se observaron en un microscopio óptico de donde se capturaron imágenes histológicas a 
20X para analizarlas con el software ImageJ y establecer la densidad óptica (DO) y densidad óptica integrada (DOI). Los datos se analizaron con un test ANOVOA y LSD Fisher. A los 7 días se observó la presencia de OPN solo en las partículas de MOD donde la DO: 0,109 y DOI: 3587,043; a los 15 días OPN marcaba distintos sitios de condensaciones colágenas y células en su interior, en este período DO fue 0,096 y la DOI: 10593,08. A los 21 y 30 días OPN señalaba trabéculas óseas, osteocitos, osteoblastos, osteoclastos y condrocitos hipertróficos inmediatos a las zonas de osificación, la DO fue 0,134 y DOI 14.639,7. A los 120 y 156 días OPN se encontraba uniformemente distribuida por la matriz del hueso nuevo con una D0: 0,0104; DOI: 4160,96 y DO: 0,081 y DOI 8878,9 respectivamente. Las DO y DOI mostraron diferencias significativas $(p<=0,05)$ entre los $7,15,21$ y 30 días y no existió diferencia a los días 120 y 150 días $(p=0,05)$. OPN se halló presente en las partículas de MOD e incrementó las densidades ópticas a los 15, 21 y 30 días como producto del metabolismo celular posibilitando la adhesión celular y luego interviniendo en la biomineralización.

Palabras claves: conejo, hueso osteopontina, inmunomarcación matriz ósea desmineralizada

Fecha de recepción artículo original: 09-08-2018

Fecha de aceptación para su publicación: 06-02-2019

\section{Introduction}

Demineralized bone matrix (DBM) is used in orthopaedic surgery as a bone substitute to repair wide defects due to its osteoinductive nature. ${ }^{(1)}$ It is constituted by the organic elements which constitute the bone matrix, among them collagen type I, bone morphogenic protein (BMP), osteocalcin (OC), osteopontin (OPN), bone sialoprotein (BSP) and osteonectin ${ }^{(2,3)}$

OPN is the most abundant non-collagen protein in the extracellular matrix. ${ }^{(4)}$ It plays a role in various physiological and molecular processes, such as the stimulation of cell-cell adhesion, the rise of extracellular cell-matrix communication, ${ }^{(5,6,7)}$ it stimulates the early differentiation of the osteoblasts, ${ }^{(8)}$ it promotes the migration of immune and tumoral cells, and it also diminishes cellular death and makes biomineralization of extracellular matrix possible..$^{(9,10)}$

The aim of the present article is to establish the spatial and temporal presence of OPN during the repair process of orthopaedic bone 
defects treated with DBM processed following a protocol previously informed by the authors.

\section{Materials and methods}

The experiments were done following the norms for care of the Faculty of Veterinary Sciences of the National University of La Pampa. Thirty sexually mature male and female rabbits were used, which were kept in individual cages and fed with a balanced formula and ad-libitum water. After the rabbits became accustomed to the living conditions the experiment began.

The rabbits were sedated with $0,1 \mathrm{mg} / \mathrm{kg}$ of diazepam (Diazepam $\AA$, Lab Zoovet, Arg), 0,01 mg/kg IM of acepromacina (Acedan ${ }^{\circledR}$, Lab Holliday, Arg) and were anaesthesized with $40 \mathrm{mg} / \mathrm{kg}$ IM of ketamina (ketamina $50 \AA$, Lab Holliday, Arg). In each animal one of the thoracic limbs was prepared to be operated in aseptic conditions. The radial diaphysis was approached through the dorsal side of the forearm where a defect was created equivalent to twice the diameter of the diaphysis, ${ }^{(11)}$ which meant that it would not heal spontaneously in the animal's life.

The defects were filled with demineralized bone matrix which was processed following a protocol previously informed by the authors. ${ }^{(12)}$ Briefly, the technique consisted in using diaphysis of the long bones of rabbits whose soft tissue was extracted at $4^{\circ} \mathrm{C}$. The diaphysis was fragmented until particles of 100 to $750 \mu \mathrm{m}$ were obtained. Lipids were extracted from the fragmented bone with a chloroform: methanol solution and then it was demineralized with chloridric acid (HCl) $0.6 \mathrm{~N}$. After stabilizing the $\mathrm{pH}$ in 7.0, it was preserved in ethylic alcohol $95^{\circ}$ at $4^{\circ} \mathrm{C}$ until used.

After filling the defects, the extensor muscles were sutured with poligalactine (Vicryl ${ }^{\circledR}$, Ethicon, USA) and the subcutaneous tissue and skin were sutured following routine/usual techniques. After the surgery, the rabbits received 1.000.000 IU of bencilpeniciline and dihidroestreptomicine (Dipenisol®, Lab. Bayer, Arg) and non-steroid antiinflamatory, Ketofen $0.1 \mathrm{mg} / \mathrm{kg}$ (Kalmavet $®$, Lab Vetanco, Arg) for 3-5days.

The rabbits were divided into six groups according to a specific time of euthanasia at 7, 15, 21, 60 and 150 days post-operatively in groups of 5 animals. The defined region of interest was the entire orthopaedic defect. The samples were fixed with buffered saline formaldehyde, they were dehydrated with batteries of alcohols of growing graduation, to be included in paraffin. Histological cuts corresponding to the 
provoked and treated defects were done of approximately $4 \mu \mathrm{m}$ with microtome (Microtom) and 3-4 cuts were placed on each microscope slide. The histological cuts were immune marked OPN by means of an immunohistochemical technique.

\section{INMUNOHISTOCHEMICAL TECHNIQUE}

Once the paraffin was removed from the cuts, they were rehydrated and treated with hydrogen peroxide at $3 \%(\mathrm{v} / \mathrm{v})$, then they were washed with PBS and later they were incubated with the antibody for OPN (AKm2A1: sc-21742; Santa Cruz Biotechnology, Inc, USA) during 1 hour at room temperature in a wet chamber. Then, they were washed with phosphate buffer saline solution (PBS pH 7.2) and incubated during 20 minutes with the second antibody with biotin (made up by anti-rabbit, anti-mouse and anti-goat immunoglobulin with biotin). After being washed again with PBS were treated with the complex streptavidine combined with peroxidase (LSAB®+Systems HRP, Dako Cytomation). After the period of incubation, they were washed and treated with the solution of cromogen substratum 3,3'-daiminobenzidina (DAB). Then the cuts were contrasted with Mayer hematoxiline, washed with ammonium hydroxide solution, dehydrated in a battery of alcohol of growing concentration and mounted with Entellan (Merck, Alemania).

The expression of OPN was established positive when the extracellular and cytoplasm of osteoblast, osteocyte and osteoclast was dyed brown.

\section{ANALYSIS OF OPTIC DENSITOMETRY (OD) AND INTEGRATED OPTIC DENSITOMETRY (IOD)}

Images were taken from the immune-marked cuts with a 200X magnification using an Axiophot optic microscope (Carl Zeis, Germany) fit to a digital camera Powershot (G6, 7.1 megapixeles, Canon INC, Japan) which used the software AxioVision 4.6.3 (Carl Zeis, Germany). The images corresponded to the new DBM particles, osteochondroid tissue, of the ossification phase and of the new trabecular bone and mature bone. The images were analysed following the methodology previously informed by Vasconcellos et al., (2014) $)^{(13)}$

The immune-markedness of OPN was quantified calculating the optic density (OD) and the integrated optic density (IOD). To calculate the OD and IOD the images of the histological cuts were loaded in the software ImageJ 1.49b (Media Cybernetics, USA). This turned 
the brown colour of the expression of OPN into grey in a scale that extends from 0 to 255 ( 0 corresponding to white and 255 to black). The optic density was calculated using the formula: OD $=\log _{10}$ (TI/ II); the TI is the transmitted intensity (equivalent to 255) and the II is the incident intensity, the media of the grey in the image analysed by the software. The integrated optic density (IOD) is obtained from the product between the OD and the surface unit expressed in square microns $\left(\mu^{2}\right)$ occupied by the expression of OPN, given the formula IOD $=(O D * A R E A)$. The result of both formulas was expressed in arbitrary units (AU).

\section{STATISTICAL ANALYSIS}

The obtained data was loaded in the software Infostat ${ }^{(14)}$ with which the descriptive statistics was carried out. The medias of each period of study was analyzed with ANOVA and Fisher LSD test to compare multiple groups. The statistical signification was defined as $\mathrm{p}<0.05$

\section{Results}

The histological studies carried out on the obtained samples following the postsurgical temporal sequence showed a complete repair of the defects from 60 days on. The histological and immunohistochemical observations corresponding to each period of study are described below.

At day 7 post-treatment, OPN was distributed homogenously in the matrix, with greater intensity in the central channels of the osteons and osteocytes lacunae (Fig. 1). The OD was 0.08 ( \pm 0.09 ; min: 0.008max: 0.50) and IOD 1.64 ( \pm 2.11 ; min: 0.05-max: 7.37 (Table 1) (Fig. 2).

At day 15 post-surgery, OPN was found in the DBM particles and in the MC particles that surrounded the former (Fig.1b). In the ossification sites the OPN was immunoexpressed in the extracellular matrix, where the transition from cartilaginous matrix to bone matrix was evident (Fig.1c). It was immunodetected in the hypertrophic chondrocytes near the areas of ossification and in the edges of the chondroplasts and chondrocels. It was also immunomarked in the pre-osteoblasts that proliferated and they differentiated into osteoblasts (Fig.4). In the bone spiculas, it was immunodistributed in a heterogeneous way in the matrix, with greater intensity in the surfaces surrounding the osteocytes included in the matrix. In the spaces constituted between the spiculas it immunoexpressed in the cytoplasm and cellular membranes of the preosteoblasts, osteoblasts and osteoclasts (Fig.3A). The 
OD of the OPN in the studied period was $0.20( \pm 0.09$; min: 0.11-max: 0.33 ) while the IOD was 9.26 ( \pm 11.92 ; min: 0.97-max: 32.60) (Table 1) (Fig. 2)

At day 21, OPN was immunodetected in the ossification sites where it was found in the cytoplasm of the hypertrophic chondrocytes adjacent to the new bone and in the edges of the chondroplasts that contained them. In the guideline spiculas, OPN was present in the extracellular matrix, the osteoid, the osteocytes, osteoplasts and osteoclasts. In the erosion lines, the osteoclasts expressed OPN in the cytoplasm, in the cuboidal osteoblasts and in the osteoid (Fig. 4A). In the new bone spiculas, OPN was immunomarked in the extracellular matrix, osteoblast, osteoclasts and osteocytes. In the intertrabecular spaces OPN was found in the preosteoblasts and osteoblasts (Fig. 4B). In this repair phase the OD was $0.17( \pm 0.05$; min: 0.11 -max:0.28) while the IOD was registered in $6.22( \pm 3.22$; min:2.83-max:13.78) (Table 1$)$.

After 30 days, OPN was found in the same histological sites reported at day 21. In the cartilaginous tissue, it was found in some hypertrophic chondrocytes near the ossification site. In the ossification places there were immunomarked chondroplasts, others were fused and contained osteoblasts which were also immunomarked OPN (Fig. 5). OPN was also the constitutive element of the bone trabecules, in which it presented heterogenous densities of greater optic density in the osteocytes and in the matrix surrounding them. At day 30, the OD was 0.140 (min: 0.082-max: 0.284) and the IOD, 2.522 (min: 0.086-max: 8.074) (Table 1).

At day 60 post DBM implant, OPN was found distributed in a heterogeneous way in the lamellar bone, in the matrix of the trabecula. In the lamellar bone it was also found in the osteocytes and in the matrix which constituted the lamellae. In the trabecular bone, it was found in the surface over which there were morphologically flat osteoblasts (Fig.6). The OD was $0.10( \pm 0.07$; min: 0.01-max: 0.21$)$ and the IOD 0.48 ( \pm 0.60 ; min: 0.01-max: 1.61) (Table 1 ).

At day 150, OPN was distributed in the bone matrix where it appeared in circular deposits coinciding with the concentric lamillae of the osteons (Fig. 7).

The ANOVA and LSD Fisher contrast analysis for OPN showed statistically significant differences ( $p>0.05)$ at days 7,21 and 150 . The same statistical analysis for IOD showed that there were statistically significant differences $(p>0.05)$ of the $\mathrm{AU}$ registered at day 15 with respect to days 7,21 and 60 . 


\section{Discussion}

The expression of OPN in the DBM particles showed that the demineralization process did not remove the matrix. Its permanence had the benefit that it allowed the mesenchymal cells and osteoclasts adhesion to the surfaces. The authors could not establish if the values of these parameters were significant, since they did not find any previous publications registering OD or IOD values. However, both types of density were significantly inferior to the registered since day 15, 21 and 30, as the present cells synthesized OPN during those periods, raising its presence and intensity markation.

From day 15 DBM particles, mesenchymal tissue condensations and bone spiculas were observed in the interior of the defects. The condensations generated new cartilage which ossified and finally repaired the defect. This process generates chondroid bone, an intermediate tissue between bone and cartilage. It derives directly from cells like to chondrocytes as a product of the transition from fibrous tissue to bone tissue. The process occurs gradually and in consecutive form without invasion of vascular capillaries ${ }^{(15)}$.

The presence of the protein in the first phases, specifically in the collagen fibres surrounding the mesenchymal cell type suggests that OPN is a necessary condition to facilitate the proliferation and migration of preosteoblasts ${ }^{16)}$

The same condition is present in the matrix to make osteoblastic proliferation in the trabecular surface possible. ${ }^{(17)}$ The OPN which was surrounded the oval cytoplasm cells contained in the matrix suggests that the pre-osteoblasts synthesize them.

Between day 15 and 30 OPN was expressed in the osteoclasts and osteoblasts, in the osteoid and in the ossification area. The immunomarcation of OPN in the osteoblasts and in the osteoid showed differentiation of the pre-osteoblasts in immature osteoblasts. OPN in the osteoid contributed to the fixation of the osteoblasts and osteoclasts in the surfaces of spiculas and trabecules and at the same time it made the biomineralization of the extracellular matrix possible. With regard to the cartilaginous tissue immediate to the ossification zone, the authors detected OPN in some of the hypertrophic chondrocytes, as reported by Lian et al., (1993) ${ }^{(18)}$ However, it can be inferred that it is a process of transchondral ossification or cellular transdifferentiation where the chondrocytes differentiate on a continuum into osteoblasts. ${ }^{(19,20,21,22,15,23)}$ Recent investigations showed that the cellular transdifferentiation comes from a continuous lineage of chondroblasts which differentiate into osteoblasts ${ }^{(24,25,26)}$ coming from cells called osteoprogenitor chondrocytes (OC) which can generate a population of 
osteoblasts in vivo and in vitro. ${ }^{(27)}$ This allowed the authors to infer that the cells which marked OPN are OC synthesizing the non-collagen protein.

OPN made the cellular adhesion possible due to its interaction with integrin $\alpha_{\mathrm{v}} \beta_{3}$ and the transmembrane CD44 protein of the osteoblasts and osteoclasts. ${ }^{(9,10)}$ For this reason, the OPN synthesis of part of the mesenchymal tissue conditions the initiation of the repair with the formation of new bone which allows the adhesion of osteoblasts and intervenes in the cellular differentiation.

The histological evidence did not establish that the DBM particles repaired the defects by ostoconduction mechanisms. Instead, the mesenchymal condensations that initiated ostogenesis were produced from them. The presence of osteoclasts at day 15 alludes to the fact that these recognized the demineralized matrix and absorbed it exposing the BMP molecules it contains. The evidence of positive chemotaxis that the MOD particles exerted on the $\mathrm{CM}$ as well as the proliferation and differentiation into chondrocytes and these into preosteoblasts, osteoblasts and osteocytes indicate that DBM exerted osteoinduction in the repair site. ${ }^{(28)}$

The OD and IOD resulted in a useful tool to quantify the OPN immunosuppression. In this way, the authors obtained objectively the expression of density for each studied period and could establish statistically significant differences that allowed them to infer the transcendence of the expression.

The OD and IOD showed a marked increment at day 15 of treatment to later diminish towards day 60 and it increased again at day 150 . The curves showed that the major metabolic OPN synthesis activity occurred at day 15 and although it diminished towards day 60 there never was total absence of OPN. The new increase of density observed at day 150 corresponded to the bone adaptive remodelling which became more intense and therefore incorporated more minerals.

The variations in the arbitrary units in which the OD and the IOD are expressed can be attributed to the fact that the OD in each period represented the media that correspond to both the immunosignalling of the bone matrix and the cells in which it expressed. In this sense, the highest values corresponding to the IOD can be attributed to the fact that the medias of the density were concentrated by square micron.

The graphic representations of the OD and the IOD had a similar behaviour with a higher density of expression towards day 15 and then it decreased slowly towards day 60, when it started to increase, although with lower values than those registered at day 15 . These variations of density suggest that the greater metabolic activity was registered in this period because of the cellular proliferation and of the expression 
of immature osteoblasts recently differentiated. On the other hand, the Od and IOD of OPN synthesized by the CM were quantified.

The decrease in the expression of OPN between days 21 and 60 can be interpreted as the result of the decrease in the cellular proliferation followed by the decrease of differentiation of pre-osteoblasts in osteoblasts, measured through the OD and IOD between days 21 and 60 . The increase in the expression observed since day 60 to day 150 would correspond to the bone adaptive remodelling to the functional member ${ }^{(8)}$. established the role of OPN in the bone remodelling due to the interrelation between osteoblasts and osteoclasts increasing the biomineralization. This adaptive remodelling requires the increase of minerals, for which a higher expression of OPN is required.

\section{Conclusion}

The present work offers a new view of the role of OPN in the repair of experimental orthopedic bone defects treated with DBM. By means of IHQ techniques quantified by OD and IOD, the authors established the expression and intensity of manifestation of OPN during the period of repair of the defects and their remodelling. Even though OPN is not a protein that intervenes in the cellular differentiation, its expression made proliferation and migration of preosteoblasts and osteoblasts possible while the process of biomineralization of the new bone matrix was on its way.

Table 1. Optic Density (OD) and Integrated Optic Density (IOD) of OPN in each of the studied periods

\begin{tabular}{|c|c|c|}
\hline & OD & IOD \\
\hline 7 days & $\begin{array}{c}0,08 \\
( \pm 0,09)(\min : 0,008 \max : 0,50)\end{array}$ & $\begin{array}{c}1,64 \\
( \pm 2,11)(\min : 0,05 \max : 7,37)\end{array}$ \\
\hline 15 days & $\begin{array}{c}0,20 \\
( \pm 0,09)(\min : 0,11 \text { max:0,33) }\end{array}$ & $\begin{array}{c}9,26 \\
( \pm 11,92)(\min : 0,97 \max : 32,60)\end{array}$ \\
\hline 21 days & $0,17( \pm 0,05)(\min : 0,11 ; \max : 0,28)$ & $\begin{array}{c}6,22 \\
( \pm 3,22)(\min : 2,83 \max : 13,78)\end{array}$ \\
\hline 30 days & $0,14( \pm 0,06)(\min : 0,08 ; \max : 0,28)$ & $\begin{array}{c}2,52 \\
( \pm 3,23)(\min : 0,09 ; \max : 8,07)\end{array}$ \\
\hline 60 days & $\begin{array}{c}0,10 \\
( \pm 0,07)(\min : 0,01 ; \max : 0,21)\end{array}$ & $\begin{array}{c}0,48 \\
( \pm 0,60)(\min : 0,01 ; \max : 1,61)\end{array}$ \\
\hline 150 days & $\begin{array}{c}0,35 \\
( \pm 0,41)(\min : 0,14 ; \max : 0,97)\end{array}$ & $\begin{array}{c}3,80 \\
( \pm 3,36)(\min : 1,27 \text { max:8,37) }\end{array}$ \\
\hline
\end{tabular}




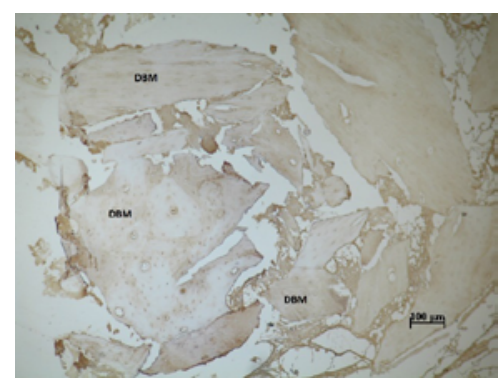

a

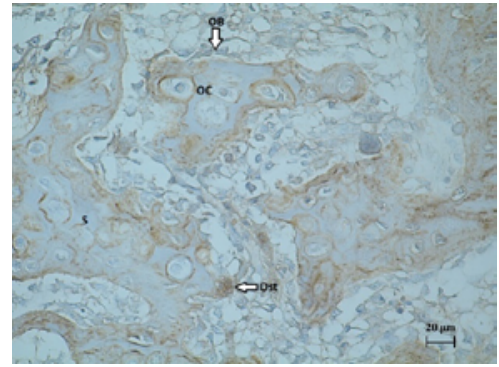

c

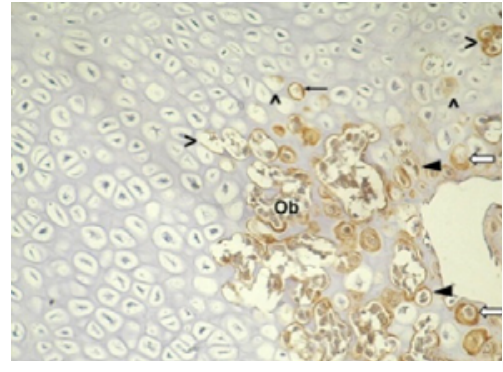

e

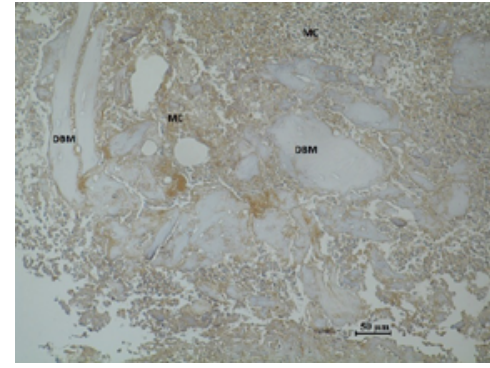

b

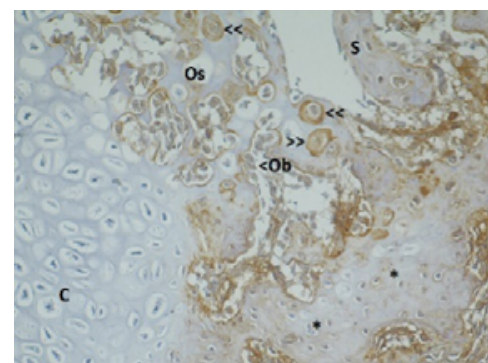

d

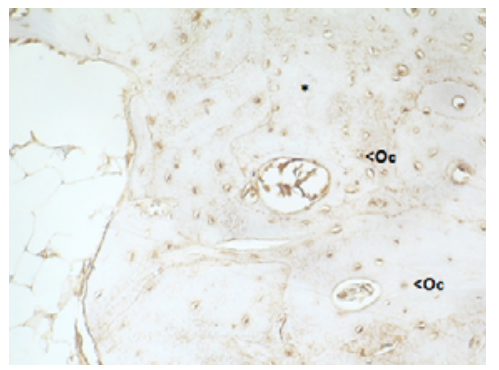

f

Fig. 1. a) Immunomarkation of OPN in the DBM particles at 7 days post-surgery. 100X; b) Immunomarkation of OPN in orthopedic bone matrix treated with DBM 15 days post-surgery, OPN is signaled in the DBM particles and in the mesenchimatic cells (MC) 200X. c) OPN inmunodetected in the bone spiculas (S) on the surfaces and surrounding cells included en bone spicula (Oc), in osteoclasts (Ost) and osteoblasts (Ob). 400X; d) Immunodetection of OPN at day 21 post-treatment, the image includes cartilage (C), mesenchimatic tissue where the mesenchimatic cells (MC) are marked, an ossification area (Os) where cells phenotypically similar to hypertrophic chondrocytes signalling OPN («); in the ossification área there were osteoblasts (Ob) marked by OPN like in the extracelular bone matrix (*) of the spiculas (S). 200X; $\boldsymbol{e}$ ) Immunomarkation of OPN at day 30 , ossification of cartilaginous tissue (Os), the more remote condrocytes start to show OPN in their cytoplasms $(>)$, later signaled in the borders of chondroplasts $(\leftarrow)$ some chondroplasts have two cells in their interior $(\triangleright)$. The chondroplasts and internal cells marked by OPN $(\hookleftarrow)$ fuse $(>)$ creating spaces ocupied by osteoblasts $(\mathrm{Ob})$ are deposited 400X. $f$ ) At 60 days post-surgery. OPN immunomarked homogenously in the bone matrix $\left(^{*}\right)$ and with greater intensity in the osteocytes (Oc). 200X. 

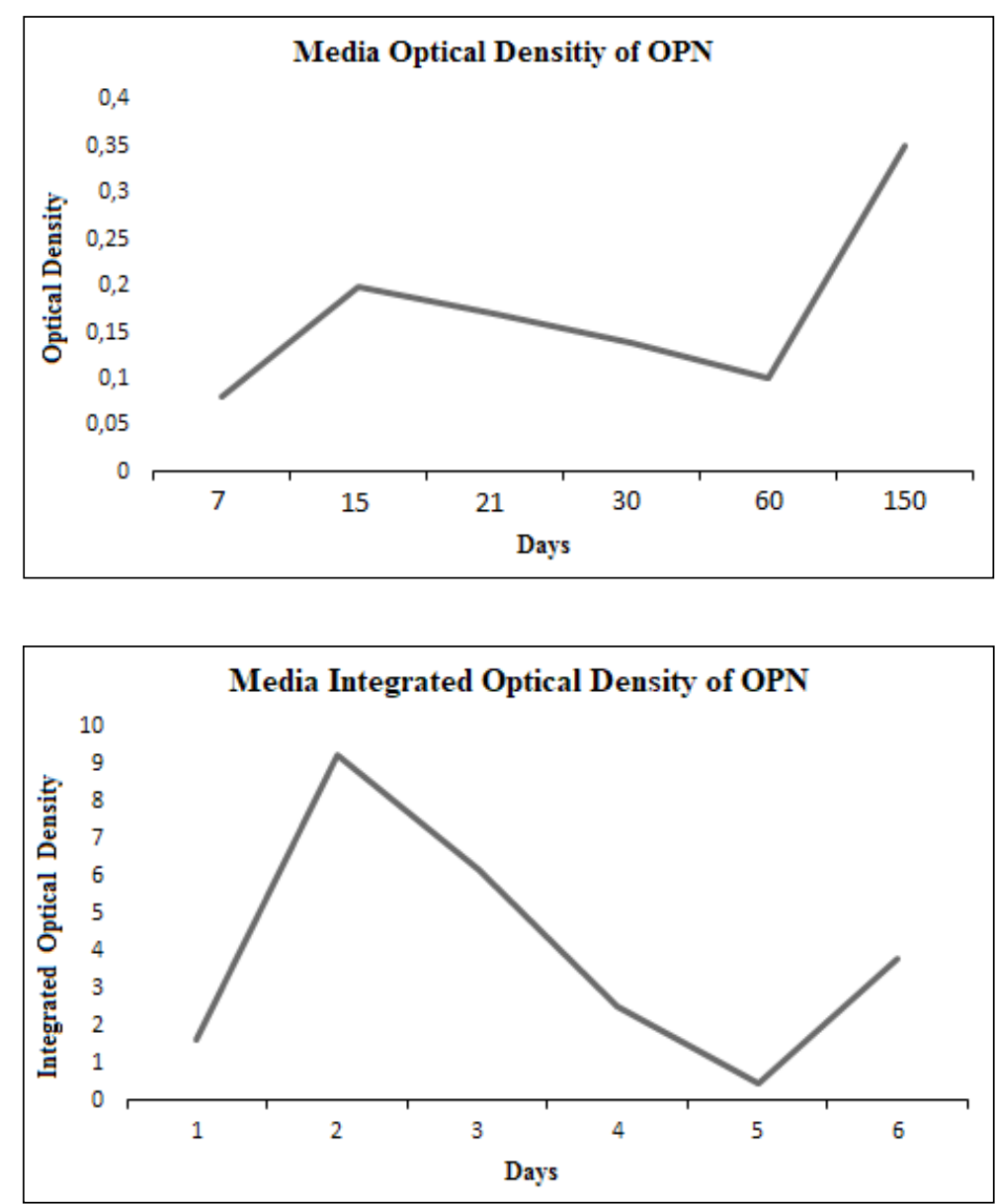

Fig. 2. Graphic representation of the media OD and IOD of OPN in the studied period. 


\section{References}

1. Urist, M. R. Bone formation by autoinduction. Science.1965; 150:893-899.

2. Colnot, C., D. M. Romero, S. Huang \& J. A. Helms.Mechanism of action of demineralized bone matrix in the repair of cortical bone defects. Clinical Orthopaedic Related Research. 2005; 435:69-78.

3. Eppley, B. L., W. S. Pietrzak \& M. W. Blanton. Allograft and alloplastic bone substitutes: a review of science and technology for the craniomaxillofacial surgeon. Journal of Craniofacial Surgery. 2005; 16:981-989.

4. McKee, M. D., C. M. Farach, W. T. Butler, P. V. Hauschka \& A. Nanci. Ultrastructural immunolocalization of noncollagenous (osteopontin and osteocalcin) and plasma (albumin and alpha 2HSglycoprotein) proteins in rat bone. Journal of Bone Mineral Research. 1993; 8:485-496.

5. Weber, G. F., S. Ashkar, Glimcher, M. J. \& H. Cantor. Receptor-ligand interaction between CD44 and osteopontin (Eta-1). Science. 1996; 271:509-512.

6. Chellaniah, M. A, K. A. Hruska. The integrin alpha(v)beta(3) and CD44 regulate the actions of osteopontin on osteoclast motility. Calcified Tissue International. 2003; 72:197-205.

7. Zhu, B., K. Suzuki, H. A. Goldberg, S. R. Rittling, D. T. Denhardt, C. A. McCulloch \& J. Sodek. Osteopontin modulates CD44-dependent chemotaxis of peritoneal macrophages through G-protein-coupled receptors: evidence of a role for an intracellular form of osteopontin. Journal of Cell Physiology. 2004; 198: 155-167.

8. Uemura, T., A. Nemoto, Y. K. Liu, H. Kojima, J. Dong, T. Yabe, T. Yoshikawa, H. A. Ohgushi, T. Ushida \& T. Tateishia. Osteopontin involvement in bone remodeling and its effects on in vivo osteogenic potential of bone marrow-derived osteoblasts/porous hydroxyapatite constructs. Materials Science and Engineering. 2001; 17:33-36

9. Sodek, J., B. Ganss \& M. D. McKee. Osteopontin. Critical Review in Oral Biology and Medicine. 2000; 11: 279-303.

10. Lesley, J., R. Hyman, P.W. Kincade. Hyaluronan binding by cell surface CD44. Journal of Biological Chemistry. 2000; 275:26967-26975.

11. Hollinger, J. O. \& J. C. Kleinschmidt. The critical size defect as an experimental model to test bone repair methods. Journal of Craniofacial Surgery. 1990; 1:60-68

12. Audisio, S. A., P. G. Vaquero, P. A. Torres, E. C., L. N. Ocampo, V. Ratusnu, A. L., Cristofolini, C. I. Merkis. Obtención, caracterización y almacenamiento de matriz ósea desmineralizada. Revista de Medicina Veterinaria. 2014; 95:27-34

13. Vasconcellos, A., C. Cisternas \& M. Paredes. Estudio inmunohistoquímico comparativo del receptor de estrógeno en tejido endometrial de ovejas razas Texel y Araucana. International Journal of Morphology. 2014; 32:1120-1124

14. Di Rienzo, J.A., F. Casanoves, M.G. Balzarini, L. Gonzalez, M Tablada \& C.W. Robledo. InfoStat versión Grupo InfoStat, FCA, Universidad Nacional de Córdoba, Argentina. 2010 . 
15. Yasui, N., M. Sato, T. Ochi, T. Kimura, H. Kawahata, Y. Kitamura \& S. Nomura. Three modes of ossification during distraction osteogenesis in the rat. Journal of Bone and Joint Surgery.1997; 79,:824-830

16. Radomisli, T. E., D. C. Moore, H. J. Barrach, H. S. Keeping \& M. G. Ehrlich.. Weight-bearing alters the expression of collagen types I and II, BMP 2/4 and osteocalcin in the early stages of distraction osteogenesis. Journal of Orthopedic Research. 2001; 19:1049-1056

17. Jang, J. H. \& Kim J.H. Improved cellular response of osteoblast cells using recombinant human osteopontin protein produced by Escherichia coli. Biotechnology Letter. 2005; 27:1767-1770.

18. Lian, J. B., M. D. McKee MD, Todd AM, Gerstenfeld LC. Induction of bone-related proteins, osteocalcin and osteopontin, and their matrix ultrastructural localization with development of chondrocyte hypertrophy in vitro. Journal of Cellular Biochemistry. 1993; 52:206-219

19. Silbermann, M., D. Lewinson, H. Gonen, M. A. Lizarbe \& K. von der Mark K. In vitro transformation of chondroprogenitor cells into osteoblasts and the formation of new membrane bone. The Anatomy Record. 1983; 206: 373-383.

20. Moskalewski, S. \& J. Malejejcyk.. Bone formation following intrarenal transplantation of isolated murine chondrocytes: chondrocyte - bone cell differentiation. Development. 1989; 107: 473-480

21. Thesingh, C. W., Groot, C. G. \& A. M. Wassenaar.Transdifferentiation of hypertrophic chondrocytes into osteoblasts in murine fetal metatarsal bones, induced by co-cultured cerebrum. Bone and Mineral Research.1991; 12:5-40.

22. Descalzi Cancedda, F., C. Gentili, P. Manduca \& R. Cancedda. Hypertrophic chondrocytes undergo further differentiation in culture. Journal of Cellular Biology. 1992; 117:427-435

23. Enishi, T., K. Yukata, M. Takahashi, R. Sato, K. Sairyo K, N. Yasui. Hypertrophic chondrocytes in the rabbit growth plate can proliferate and differentiate into osteogenic cells when capillary invasion is interposed by a membrane filter. 2014; PLOS ONE 9, e104638

24. Yang, G., L. Zhu, N. Hou, Y. Lan, X. M. XM, B. Zhou, Y. Teng \& X. Yang. Osteogenic fate of hypertrophic chondrocytes. Cell Research. 2014a;24:1266-1269.

25. Yang, L., K. Y. Tsang, H. C. Tang, D. Chan \& K. S. Cheah.. Hypertrophic chondrocytes can become osteoblasts and osteocytes in endochondral bone formation. Proceedings of National Academy Science. 2014b; 111:12097-12102.

26. Zhou, X., K. von der Mark, S. Henry, W. Norton, H. Adams, B. de Crombrugghe.. Chondrocytes transdifferentiate into osteoblasts in endochondral bone during development, postnatal growth and fracture healing in mice. PLoS Genetics. 2014; 10, e1004820

27. Jung, P., M. Gebhardt, S. Golovchenko, F. Perez-Branguli, T. Hattori, C. Hartmann, X. Zhou, B. deCrombrugghe, M. Stock, H. Schneider \& K. von der Mark. Dual pathways to 
endochondral osteoblasts: a novel chondrocytederived osteoprogenitor cell identified in hypertrophic cartilage. Biology Open. 2015; 4,608-621.

28. Kawakami, T. Immunohistochemistry of BMP induced heterotopic osteogenesis. Journal of Hard Tissue Biology.2001; 10:73-76. 